\title{
Peran Trend dan Motif HijrahTerhadap Pembelian Busana Muslimah Di Kota Palu
}

\author{
Umi Wahyuni $\mathrm{MD}^{1 *}$, Siti Achiria ${ }^{2}$ \\ ${ }^{1}$ Pascasarjana Fakultas Ilmu Agama Islam (FAI) Universitas Islam Indonesia, email: umiwahyuni.md@gmail.com \\ ${ }^{2}$ Pascasarjana Fakultas Ilmu Agama Islam (FAI) Universitas Islam Indonesia, email: siti.achiria@uii.ac.id
}

ABSTRAK

Pertumbuhan industri halal di Indonesia telah menunjukkan perkembangan yang sangat pesat dalam beberapa tahun belakangan, baik dibidang kuliner, fesyen, wisata, kesehatan dan kosmetik. Hal ini terlihat dengan banyaknyaajakan untuk menerapkanhalal life style dari berbagai komunitas muslim Indonesia. Adanya gerakan hijrah yang banyak dilakukan oleh berbagai kalangan masyarakat dan didukung dengan penggunaan produk halal yang telah menjadi trend di kehidupan sehari-hari memberi dampak terhadap peningkatan permintaan konsumen pada produk-produk halal termasuk juga busana muslimah. Penelitian ini merupakan penelitian deskriptif kualitatif dengan jenis penelitian lapangan (field research) dengan cara melakukan wawancara dan observasi terhadap pelaku hijrah dan pedagang busana muslimah di Kota Palu.Tujuan dari penelitian ini adalah untuk mengetahui bagaimana peran trend dan motif hijrah seorang muslimahterhadap pembelian busana muslimah.Hasil dari penelitian ini menunjukkan bahwatrend hijrah maupun motif yang melatar belakangi seseorang untuk berhijrah, keduanya mengambil peran dalam menentukan perilaku konsumen muslim untuk melakukan pembelian busana muslimah karena merupakan bagian dari faktor yang mempengaruhi keputusan konsumen yaitu faktor pribadi dan faktor psikologis.
INFORMASI

ARTIKEL

\section{Katakunci:}

Trend Hijrah,Busana

Muslimah, Industri

Halal, Perilaku

Konsumen 


\section{PENDAhULUAN}

Saat ini industri halal dinilai mampu berkontribusi terhadap perekonomian khususnya ekonomi syariah. Penting bagi kita untuk mengoptimalkan gaya hidup halal gunamendorong perekonomian syariah. Mengingat, jumlah penduduk Indonesia yang mayoritas muslim, tentu menjadi peluang yang sangat besar untuk mengembangkan industri halal. Di sisi lain, negara-negara lain juga sudah melihat betapa besarnya potensi dari industri halal ini.

Melihat semakin maraknya gaya hidup halal yang diterapkan oleh masyarakat, baik dalam bidang fesyen, makanan/minuman, kosmetik dan pariwisata, maka semakin besar peluang bagi para produsen untuk menawarkan barang-barang halal tersebut di masyarakat. Semakin banyak permintaan akan produk halal yang diakibatkan semakin maraknya orang-orang yg menerapkan gaya hidup halal, maka semakin banyak juga produsen yang menyediakan atau memproduksi barang dan jasa yang halal. Dampak dari gaya hidup halal ini terlihat pada kalangan wanita muslimah yang banyak merubah gaya berpakaiannya menjadi pakaian yang syar'i.

Meningkatnya pertumbuhan ekonomi Islam di Indonesia semakin diperkuat dengan adanya perubahan sikap dan perilaku masyarakat muslim untuk lebih mendekatkan diri kepada sang pencipta dan menjadi pribadi yang lebih religius, perubahan tersebut tidak hanya terjadi dalam diri namun juga berdampak pada perubahan cara bersosialisasi dan berpakaian, hal ini dikenal dengan kata berhijrah.

Sebagai negara dengan jumlah penduduk muslim terbanyak di dunia, Indonesia merupakan tempat dimanabanyak terjadi fenomena hijrah dikarenakan sebagian besar pendudukan adalah muslim. Hijrah sendiri memiliki makna berpindah, dalam hal ini terjadi perubahan sikap dan perilaku seorang muslim menjadi lebih baik dari sebelumnya, yang artinya terjadi perpindahan dari yang kurang baik menjadi lebih baik. Fenomena hijrah yang terjadi di Indonesia sudah mulai dilakukan sekitaran awal tahun 2015, hal ini juga diperkuat dengan adanya aksi gerakan bela yang terjadi pada tahun 2016 dikarenakan kasus penistaan agama yang dilakukan oleh mantan gubernur Jakarta pada masanya. Akibatnya, banyak masyarakat yang menjadi tertarik untuk mengenal agama Islam lebih dalam lagi dan salah satu cara yang dilakukan adalah berhijrah.

\section{KERANGKA TEORI}

\subsection{Trend Hijrah di Era Milenial}

Dewasa ini makna hijrah yang terjadi di kalangan umat Islam Nusantara berbeda 
dengan yang terjadi pada zaman Rasulullah SAW, Istilah hijrah saat ini digunakan sebagai ungkapan dari fenomena orang yang baru mengenal atau memperdalam keislamannya dan menjadi lebih baik dari sebelumnya. Di antara yang ramai di media sosial saat ini adalah fenomena hijrah di kalangan selebriti tanah air, trend hijrah melanda kaum muda, pelajar, mahasiswa dan berbagai kalangan masyarakat.

Hijrah secara bahasa bermakna "attarku", meninggalkan sesuatu.Sementara dalam syariat Islam, hijrah dimaknai sebagai memisahkan diri atau berpindah dari negeri kufur ke negeri Islam karena mengkhawatirkan keselamatan agama, (Lihat Muhammad bin 'Allan AsShiddiqi, Dalilul Falihin li Thuruqi Riyadhis Shalihin ${ }^{1}$.Namun demikian sebenarnya dalam konteks yang disebut terakhir, hijrah tidak melulu berpindah dari negeri kufur ke negeri Islam.Sebab pada masa awal Islam kita justru mengenal praktik yang berbeda.Karena itu, secara substansial makna hijrah tampaknya tidak terpaku pada migrasi ke negeri Islam saja, namun lebih mendasar yaitu hijrah dari suatu tempat ke tempat lain karena menjaga keselamatan agama.

\footnotetext{
${ }^{1}$ Ahmad Muntaha AM, "Fenomena Hijrah Kaum Muda", dikutip dari NU Online, https://islam.nu.or.id/post/read/95591/fenomenahijrah-kaum-muda, diakses 28 Juni 2019 jam
}

Sebab itu, hijrah bukan sekadar berjilbab lebar-lebar dan berjenggot lebatlebat.Lebih dari itu, hakikat hijrah adalah meninggalkan berbagai larangan agama.Baik larangan yang bersifat lahiriah maupun yang bersifat batiniah.Kata "hijrah" di era milenial secara umum dimaknai dalam beberapa hal, seperti: perubahan pemikiran, perubahan penampilan, menjadi muallaf (yang sebelumnya non-muslim), mengagumi ulama, menghadiri pengajian (online dan offline), mengikuti komunitas, hadir dalam gathering, dan ikut dalam solidaritas keislaman. Berbeda dengan tren hijrah generasi sebelumnya yang cenderung tertutup, generasi milenial memperlihatkan keterbukaan ketika memilih berhijrah yang terlihat dari aktivis media sosial mereka. ${ }^{2}$

Kemunculan trend hijrah pada generasi milenial saat ini memberikan pengaruh yang sangat besar terhadap diri pelakunya. Bukan hanya perubahan keimanan seseorang saja, namun juga terhadap cara berpakaian. Baik bagi pelaku hijrah laki-laki maupun perempuan samasama akan merubah cara berpakaian mereka, namun perubahan besar biasanya dilakukan oleh perempuan dengan penggunaan gamis dan jilbab syar'i dalam aktivitas hariannya. Hal ini juga secara tidak langsung akan

\footnotetext{
2 Yanuardi Syukur,Tren Hijrah dan Halal Muslim Milenial,Academia.edu. Paper online https://www.academia.edu/37101944/Tren_Hijrah_da n Halal Muslim Milenial, diakses 7 Juli 2019.
} 
mempengaruhi penjualan busana muslimah di pasaran.

Perkembangan trend hijrah tidak terlepas dari pengaruh era digital dan akses internet yang semakin mudah didapatkan. Di tengah gempuran "kebablasannya" akses informasi di era digital seperti sekarang yang notabene dapat dengan mudah mengakses informasi dalam hal negatif, justru di sisi lain masih banyak anak muda yang istiqamah menyebarkan ajakan dan motivasi hijrah dalam dunia kampus yang mana mereka dapat menyeimbangkan antara pengetahuan mengenai teknologi komunikasi dan ilmu agama dalam balutan konvergensi media dalam mengajak dan memotivasi lingkungannya untuk berhijrah. ${ }^{3}$

\subsection{Faktor pendukung dalam berhijrah}

Belakangan ini banyak dijumpai kampanye gerakan berhijrah di media sosial, baik di facebook, instagram maupun twitter, penyebaran ajakan untuk berhijrah di media sosial sendiri merupakan dampak dari penggunaan intenet yang sudah menjamur dimana-mana dan penggunanya pun dari berbagai kalangan usia. Di era globalisasi saat ini, adanya internet dapat memudahkan penggunanya untuk mengakses apa saja yang ia kehendaki, dari hal-hal positif hingga

${ }^{3}$ Erik Setiawan, dkk. "Makna Hijrah Pada Mahasiswa Fikom Unisba di Komunitas ('followers') Akun 'LINE@DakwahIslam"MediaTor, Vol. 10 (1), 28 Juni 2017. Hlm. 104 negatif sehingga banyak pengguna internet yang telah berhijrah menggunakan internet sebagai salah satu media dakwah untuk mengajak orang-orang disekelilingnya merasakan apa yang dirasakannya setelah berhijrah.

Hal tersebut terlihat dari banyaknya akun-akun di media sosial yang berisi ajakan untuk melakukan kebaikan, seperti menyebarkan kata-kata motivasi untuk berubah menjadi lebih baik, ceramahceramah dari para ustad ternama dan membentuk suatu komunitas hijrah yang aktif di dunia online maupun offline.Meskipun merupakan suatu bagian dari komunitas, namun sejatinya gerakan hijrah merupakan gerakan yang terorganisasi dan terpusat, tidak ada ketua, koordinator atau penanggung jawab utama dalam penyebarannya.

Yang menarik adalah bagaimana bisa gerakan hijrah yang tidak terkoordinasi secara resmi bisa memiliki pengaruh besar dan berlangsung dalam waktu yang cukup lama. Seorang peneliti kajian budaya pop, media, dan komunikasi, Abdul Hair, menjelaskan dalam tulisannya, ${ }^{4}$ bahwa ada dua faktor pendukung terjadinya hal tersebut, yaitu:

\footnotetext{
${ }^{4}$ Abdul Hair, Fenomena Hijrah di Kalangan Anak Muda, Detik News, dikutip dari https://news.detik.com/kolom/d-3840983/fenomenahijrah-di-kalangan-anak-muda diakses 7 Juli 2019
} 
Pertama, fenomena ini adalah salah satu dampak turunan dari kebijakan pemerintah di masa lalu.Jika melihat sedikit ke belakang, fenomena ini sebenarnya tidak mengagetkan. Ariel Heryanto, melalui buku Identitas dan Kenikmatan: Politik Budaya Layar Indonesia (2015) menyatakan bahwa telah terjadi kebangkitan Islamisasi menjelang berakhirnya kekuasaan Orde Baru. Kelompok Islam yang sebelumnya dianggap sebagai ekstrem kanan, kemudian dirangkul dan dijadikan sekutu baru pemerintahan Soeharto untuk memperkuat posisi politiknya yang saat itu tengah melemah.Itulah masa ketika penggunaan jilbab tidak lagi dilarang, dan kelompokkelompok Islam mulai menyatakan aspirasi politiknya secara terbuka tanpa perlu takut ditindas oleh rezim penguasa.Hijrah, dalam konteks ini, adalah dampak turunan dari kebijakan tersebut.

Kedua, gerakan hijrah adalah gerakan yang disponsori oleh industri.Sudah bukan rahasia lagi kalau industri mengkomodifikasikan apapun yang bisa diperjualbelikan, tidak terkecuali dalam hal ketaatan beragama.Sebelum kampanye hijrah dilakukan secara masif, industri sudah lebih dulu mengkooptasi ketaatan beragama masyarakat untuk kepentingan komersil.Hal ini bisa kita lihat dari diproduksinya pakaian dan beragam produk kecantikan seperti sabun, shampo, serta rias wajah khusus untuk muslimah. Produk-produk kecantikan ini bahkan sampai mengadakan beragam kontes kecantikan khusus untuk perempuan muslim berjilbab.

Maraknya gerakan hijrah pun tidak lepas dari dukungan industri, bukan berarti industri mendominasi keadaan dan pelaku hijrah patuh begitu saja pada apapun yang menjadi kehendak industri.Bukan juga pelaku hijrah yang mendominasi situasi, melainkan industri yang justru didikte untuk menyediakan apapun yang menjadi kebutuhan pelaku hijrah. Relasi antara pelaku hijrah dan industri lebih tepat dilihat sebagai hubungan yang dialektis dan saling menguntungkan: ketaatan menjalankan syariat Islam menemukan perwujudannya dalam sistem perekonomian yang berorientasi pada industri, dan industri memberikan respons terhadap fenomena tersebut.

Terlepas dari hal-hal tersebut diatas, yang merupakan hasil analisis dari seseorang terhadap dampak dari fenomena hijrah saat ini, sejati seseorang yang memutuskan untuk berhijrah telah berusaha untuk menjadi lebih baik dari sebelumnya dan memutuskan untuk meninggalkan kehidupannya yang lama untuk lebih mengenal agama Islam secara mendalam dan mendekatkan diri kepada Allah SWT. 


\subsection{Perilaku Konsumen dalam Perpektif} Ekonomi Islam

Fokus pembahasan Ekonomi Islam pada hakekatnya terletak pada penyikapan manusia pada harta.Termasuk didalamnya semua perilaku manusia dalam mencari harta (produksi), menyimpan harta (mengelola kekayaan) dan membelanjakan harta (konsumsi).Menurut Sakti (2003) Terdapat empat prinsip dalam sistem ekonomi Islam dalam menyikapi permasalahan tentang perilaku konsumen, termasuk konsumsi di dalamnya ${ }^{5}$ Pertama, Hidup hemat dan tidak bermewahmewah(abstain from wasteful and luxuriousliving), bermakna juga bahwa tindakanekonomi hanyalah sekedaruntukmemenuhi kebutuhan (needs) bukanmemuaskan keinginan (wants) (Qordowi, 1997). Menurut Abdul Mannan (1995) sikaptidak berlebih-lebihan dan mengutamakankepentingan orang lain adalah yang palingpenting yang diartikan secara luas.

Kedua, Implementasi Zakat (implementation ofzakat); pada tingkat negara mekanisme zakatadalah obligatory zakat system bukan voluntary zakat system.Disamping itu ada juga instrumen sejenis yang bersifat sukarela (voluntary) yaituinfak, shadaqah, wakaf, dan hadiah.

\footnotetext{
5 Ali Sakti, "Sistem Ekonomi Islam." Filosofi Dan Bangunannya (2003), dalam Kurniati, "Teori Perilaku Konsuman Perspektif Ekonomi Islam", Jurnal Ekonomi SyariahIndonesia, Vol. VI, No. 1, Juni 2016. Hlm. 48
}

Mengenaiperintah mengeluarkan zakat terdapat dalamfirman Allah (Q.S At Taubah (9) : 103). Zakat, infak, shadaqah dan sejenisnyamerupakan salah satu saluran penyeimbangdari saluran kebutuhan individual, yangdisebut sebagai saluran konsumsi sosial.Saluran ini hanya ada dalam Ekonomi Islam.

$$
\text { Ketiga, Penghapusan/pelarangan }
$$

Riba(prohibition of riba); menjadikan sistem bagihasil (profit-loss sharing) dengan instrumen mudharabah dan musharakah sebagaipengganti sistem kredit (credit system) berikutinstrumen bunganya (interest rate). Dalam Alqur'an telah dijhelaskan dalam (Q.S. Al Baqarah (2) : 275)

Keempat, Menjalankan usaha-usaha yang halal(permissible conduct); dari produk atau komoditi,manajemen, proses produksi hingga prosessirkulasi atau distribusi haruslah ada dalamkerangka halal. Usahausaha tadi tidak bolehbersentuhan dengan judi (maisir) dan spekulasi(gharar) sebagaimana firman Allah yang terdapat dalam (Q.S. Al Baqarah (2) : 168).Seorang muslim harus yakin akan adanya kehidupan setelah dunia yaitu akhirat. Dengan ini maka manusia akan melakukan dua jenis konsumsi yaitu untuk kepentingan dunia dan juga untuk akhirat.

\subsection{Faktor-Faktor Yang Mempengaruhi} Perilaku Konsumen 
Menurut William J. Stanton, ada dua kekuatan faktor yang mempengaruhi perilaku konsumen yaitu kekuatan sosial budaya dan kekuatan psikologis. Sedangkan Philip Kotler mengemukakan bahwa faktor utama yang mempengaruhi perilaku konsumen adalah faktor kebudayaan, faktor sosial, dan faktor psikologis. Pada dasarnya kedua pendapat ini sama namun dikelompokkandengan cara yangberbeda. Adapun penjabarannya menurut Mangkunegara(2012) adalah sebagai berikut ${ }^{6}$ :

\section{a. Faktor kebudayaan}

\section{Budaya}

Budaya dapat didefinisikan sebagai hasil kreativitas manusia dari satu generasi kegenerasi berikutnya yang sangat menentukan bentuk perilaku dalam kehidupan sebagai anggota masyarakat.Kebudayaan merupakan hal yang kompleks yang meliputi ilmu pengetahuan, kepercayaan, seni, moral, adat, kebiasaan dan norma-norma yang berlaku di masayarakat. Flemming Hansen mengemukakan bahwa karakteristik budaya adalah Kebudayaan adalah hasil karya manusia, prosesbelajar, mempunyai aturan/berpola, bagiandari masyarakat,

6 Anwar Prabu Mangkunegara, Perilaku Konsumen, (Bandung: Refika Aditama, 2002), dalam Kurniati, "Teori Perilaku Konsuman Perspektif Ekonomi Islam", Jurnal Ekonomi SyariahIndonesia, Vol. VI, No. 1, Juni 2016. Hlm. 46 menunjukkan kesamaantertentu tetapi pula terdapat variasi-variasinya,pemenuhan kepuasan dan kemantapan, penyesuaian, terorganisasi danterintegrasi secara keseluruhan.

\section{Sub-budaya}

Setiap budaya memiliki kelompokkelompok sub-budaya yang lebih kecil, yang merupakan identifikasi dan sosialisasi yang khas untuk perilaku anggotanya.

\section{Kelas sosial}

Kelas sosial didefinisikan sebagai suatukelompok yang terdiri dari sejumlah orang yang mempunyai kedudukan yang seimbang dalam masyarakat. Kelas sosial dapat diketegorikanke dalam upper-upper class (Kelas puncak atas; Golongan ningrat), lower-upper class (Kelaspuncak bawah; Orang-orang kaya), upper-midleclass (Kelas Menengah atas; Orang yang sukses dengan profesinya), lower-midle class (Kelas menengah bawah; Pekerja non manajerial), upper-lower class (kelas bawah atas; orang berpenghasilan relatif cukup untuk kehidupan sehari-hari), lower-lower class (kelas bawah rendah; pekerja-pekerja kasar) tingkat sosialini sangat berkaitan dengan kecenderungan perilaku pembelian.

\section{b. Faktor Sosial}

\section{Kelompok referensi}

Kelompok referensi didefinisikan sebagaisuatu kelompok orang yang mempengaruhisikap, pendapatan, norma, 
dan perilakukonsumen. Perilaku konsumen dipengaruhikelompok referensi yang menjadi anggotanya atau yang dicita-citakan. Pengaruh kelompok referensi terhadap perilaku konsumen antaralain dalam menentukan produk atau merkyang mereka gunakan sesuai dengan aspirasikelompok.

\section{Keluarga}

Keluarga didefinisikan sebagai suatu unitmasyarakat yang terkecil yang perilakunya sangat mempengaruhi dan menentukan dalam pengambilan keputusan pembelian.

\section{Peranan dan status}

Setiap orang pasti berpartisipasi denganbanyak kelompok sepanjang hidupnya. Posisiorang dalam setiap kelompok inilah disebutsebagai peran dan status. Orang-orang memilih produk yang mengkomunikasikan peran dan status dalam masyarakat.

\section{c. Faktor Pribadi}

\section{Usia dan tahap daur hidup}

Manusia memerlukan barang dan jasa sepanjang hidupnya. Perilaku ini berubah ubah sesuai perkembangan siklus keluarga. Para pemasar sering menetapkan pasar sasarannya berupa kelompokkelompok dari tahap kehidupan tertentu dan mengembangkan produk dan rencana pemasaran yang tepat bagikelompok tersebut.
Pekerjaan dapat mempengaruhi jenis konsumsi seseorang. Manajer pemasaran perlu mengidentifikasikan kebutuhan keluarga sesuai dengan pekerjaan, kemudian dapat mengkhususkan produk dan jasa tertentuuntuk kelompok pekerjaan tertentu.

\section{Macam-macam situasi ekonomi}

$$
\text { Keadaan ekonomi yang }
$$

mempengaruhi pilihan produk meliputi: pendapatan yang dapat dibelanjakan, tabungan, hutang, kekuatan untuk meminjam dan pendirian terhadap belanja dan menabung.

\section{Gaya hidup}

Gaya hidup sesorang dapat ditangkapdari kegiatan yang diikuti, minat danpendapat seseorang. Gaya hidup melukiskankeseluruhan pribadi yang berinteraksi denganlingkungan dan mencerminkan sesuatu yanglebih luas dari kelas sosial di satu pihak dankepribadian di pihak lain.

\section{Kepribadian dan konsep diri}

Kepribadian merupakan suatu bentukdari sifat-sifat yang ada pada diri individu yangsangat menentukan perilakunya. Kepribadiankonsumen sangat dipengaruhi oleh pengaruhinternal dirinya (motif, IQ, emosi, cara berpikirdan presesi) dan faktor eksternal dirinya(lingkungan fisik, keluarga, masyarakat, sekolah, lingkungan alam). Kepribadian konsumen akan

\section{Pekerjaan}


mempengaruhi persepsi dan pengambilan keputusan dalam membeli.

\section{d. Faktor Psikologis}

\section{Motivasi}

Motivasi adalah keadaan yang ada padadiri seseorang yang mendorong orang tersebutuntuk bertindak. Suatu kebutuhan menjadi satu dorongan bila kebutuhan itu muncul hingga mencapai taraf intensitas yang cukup atau mendesak.

\section{Persepsi}

Persepsi mempengaruhi tindakan seseorang pada situasi dan kondisi yang samadan apabila persepsi ada situasi berbeda maka tindakannya pun berbeda. Tantangan yang dihadapi pemasar adalah membuat rangsangan yang diperhatikan orang sehingga pesan tersebut dapat diterima oleh konsumen.

\section{Belajar}

Belajar dapat didefinisikan sebagai suatu perubahan perilaku akibat adanya pengalaman sebelumnya. Pengalaman belajar konsumen akan menentukan tindakan dan pengambilan keputusan pembelian.

\section{Kepercayaan dan sikap}

Sikap adalah suatu penilaian kognitif seseorang terhadap suka atau tidak suka, perasaan emosional yang tindakannya cenderung ke arah berbagai objek atau ide. Sikap dapat juga berarti sebagai kesiapan seseorang untuk melakukan suatu tindakan atau aktivitas. Sikap mempengaruhi keyakinan begitu pula sebaliknya, keyakinan menentukan sikap.

\section{METODE PENELITIAN}

Penelitian ini merupakan penelitian deskriptif dengan jenis penelitian lapangan (field research) yang merupakan metode penelitian kualitatif, artinya penelitian yang bertujuan mendeskripsikan hasil penelitian yang dikemukakan penulis lapangan, sehubung dengan penelitian kualitatif ini ada beberapa pendapat para ahli tentang penelitian kualitatif, antara lain Bogdan dan Taylor sebagai mana dikutip oleh Lexy J. Moleong mendefinisikan metode kualitatif yaitu sebagai prosedur penelitian yang menghasilkan data deskriptif berupa katakata tertulis atau lisan dari orang-orang dan perilaku yang diamati. ${ }^{7}$

Lokasi penelitian ini bertempat di Kota Palu, lokasi tersebut dijadikan tempat penelitian dikarenakan Kota Palu merupakan daerah yang dimana terdapat banyak penduduk muslim yang ada di Provinsi Sulawesi Tengah dan sesuai dengan pengamatan awal, banyak juga penduduk Kota Palu yang telah melakukan hijrah sehingga penulis memutuskan untuk menjadikannya sebagai lokasi penelitian. Sedangkan sumber data dalam penelitian ini

${ }^{7}$ Lexy J, Moleong, Metodologi Penelitian Kualitatif, Cet XIII, (Bandung: Remaja Rosda Karya, 2001), hlm. 3. 
merupakan data primer yang berasal dari hasil wawancara dan observasi langsung dari lapangan.

Data yang digunakan merupak data primer dan data sekunder, yang diperoleh melalui observasi atau pengamatan langsung, wawancara dan studi kepustakaan atau dokumentasi.Wawancara yang dilakukan melibatkan enam orang informan, tiga orang diantaranya adalahpelaku hijrah sedangkan tiga lainnya merupakan pedagang busana muslim yang telah memenuhikriteria informan yang dibutuhkan dengan waktu pelaksanaan wawancara yang berbeda-beda untuk menjawab pertanyaan-pertanyaan berkaitan dengan permasalahan yang akan diteliti.

\section{HASIL DAN PEMBAHASAN}

\subsection{Trend Hijrah di Indonesia}

Kata hijrah secara umum dimaknai dalam beberapa hal, seperti: perubahan pemikiran, perubahan penampilan, menjadi muallaf (yang sebelumnya non-muslim), mengagumi ulama, menghadiri pengajian (online dan offline), mengikuti komunitas, hadir dalam gathering, dan ikut dalam solidaritas keislaman. Berbeda dengan tren hijrah generasi sebelumnya yang cenderung tertutup, generasi milenial memperlihatkan keterbukaan ketika memilih berhijrah yang terlihat dari aktivis media sosial mereka. Hijrahsecara etimologis diartikan sebagai perpindahan seseorang dari suatu tempat ke tempat lain. Sedangkan menurut Islam, hijrah diartikan sebagai Keluarnya Rasulullah SAW dari Mekah, kota kelahirannya menuju Yatsrib/Madinah, suatu daerah yang lain, dengan niat dan maksud keselamatan dirinya serta pengembangan ajaran Islam yang wajib disiarkannya, dan akan kembali lagi pada suatu waktu kemudian. ${ }^{8}$ Namun pengertian tersebut berbeda dengan makna hijrah yang terjadi di Indonesia saat ini, hijrah yang terjadi saat ini lebih mengarah pada gerakan seorang muslim khususnya anak muda, untuk "berpindah" menjadi pribadi yang lebih baik dengan cara meningkatkan ketaatan dalam menjalankan syariat agama.

Perkembangan teknologi yang meningkat secara cepat $\mathrm{di}$ Indonesia membuat fenomena hijrah menjadi hal yang sering dilihat diberbagai kalangan, termasuk juga para kalangan selebritis tanah air. Hal ini membuat munculnya berbagai macam model busana muslim yang lebih modis dan modern yang dapat menunjang penampilan para muslimah Indonesia khususnya bagi para selebritis yang menjadi public figure masyarakat Indonesia. Banyaknya selebritis tanah air yang melakukan hijrah membuat para pedagang busana muslim berlomba-

${ }^{8}$ Muhammad Taufiq Ismail dan Zaenal Abidi,"Kontekstualisasi Hijrah Sebagai Titik Tolak Pembaharuan Pendidikan" Jurnal SUHUF, Vol. 29, No. 1, Mei 2017. Hlm. 55 
lomba untuk menjadikan mereka sebagai model dari busana yang dijual dengan tujuan agar busana yang dipakai para selebritas laku dipasaran. Tidakhanya dari kalangan pedagang di pasar, para selebritis yang melakukan hijrah banyak yang kemudian membuka usaha berbau islami, mulai dari bisnis kuliner, fashion, hingga bisnis travel.Peluang ini dimanfaatkan sebaikbaiknya oleh para selebritis untuk membangun self branding dalam dunia bisnis khususnya dalam bidang fashion, mengingat banyak masyarakat awam yang menjadikan para selebritis muslimah sebagai role model mereka dalam berbusana khususnya bagi yang baruberhijrah.

Kemunculan trend hijrah sendiri memberikan dampak positif bagi para penjual di Indonesiayang berorientasi pada penjualan industri halal seperti kosmetik, makanan, pakaian hingga wisata yang berbau halal, khususnya pada penjual busana muslimah.Trend hijrah juga berdampak pada semakin banyak permintaan akan pakaian syar'i seperti busana dan jilbab. Hal ini dimanfaatkan sebaik-baiknya bagi para produsen untuk memproduksi pakaian syar'i.Saat ini dapat dilihat banyaktoko maupun butik yang menjual busana muslimah dengan berbagai model dan harga yang berbeda-beda, ini disebabkan karena para pelaku hijrah harus memperbanyak koleksi busana muslimah yang merupakan pembeda disaat sebelum dan sesudah mereka berhijrah, hal ini secara tidak langsung memicu adanya peningkatan permintaan busana muslimah di masyarakat.

\subsection{Motif Hijrah Bagi Pelakunya}

Berdasarkan hasil wawancara yang telah dilakukan, terdapat beberapa motif yang mendasari seseorang dalam berhijrah diantaranya adalah dorongan dari dalam diri, dorongan masa lalu, dorongan dari masa depan, dan adanya pengaruh dari orangorang sekitar.

a. Dorongan Dari Diri Sendiri

Dalammelakukan perubahan dalam hidup, salah satu yang paling mempengaruhi adalah diri kita sendiri. Begitupun yang diungkapkan oleh salah satu informan dalam penelitian ini, ia menyebutkan bahwa salah satu alasan mengapa ia memutuskan untuk berhijrah adalah karena merasa lelah dengan kehidupannya saat ini yang jauh akan syariat agama Islam. Mulai dari cara berpakaian yang masih terbuka hingga pergaulan dengan orang-orang yang menurutnya tidak membawanya pada kebaikan dunia maupun akhirat sehingga timbul keinginan dari dalam diri untuk memperbaiki kehidupannya dan lebih mendekatkan diri kepada sang pencipta. Menurutnya hijrah merupakan satusatunya carayang tepat untuk 
meninggalkan kehidupannya yang sekarang dan berubah menjadi pribadi yang lebih baik.

b. Dorongan Masa Lalu

Merupakan dorongan untuk berhijrah yang muncul akibat perbuatan yang pernah ia lakukan.Seperti yang ditemui oleh salah satu informan yang mengatakan bahwa seketika ia merasa sangat terganggu dengan dosa-dosa yang pernah ia lakukan di masa lalu dan ganjaran yang akan diterima dari Allah SWT baik semasa hidup di dunia ataupun di akhirat kelak. Sehingga pada akhirnya ia berpikir untuk mencari cara agar dapat keluar dari perasaan yang sangat mengganggu tersebut dan mendekatkan diri kepada Allah dan memohon ampunan-Nya merupakan jalan terbaik yang ia pilih untuk menenangkan hatinya. Adanya pemikiran bahwa melakukan perbuatanperbuatan yang tidak baik dapat menjauhkan kita dari orang-orang yang disayangi semakin memantapkan niatnya untuk melakukan hijrah.

c. Dorongan Masa Depan

Selanjutnya merupakan dorongan dari masa lalu.Salah satu informan dalam penelitian ini mengungkapkan bahwa apabila ingin mendapatkan kebaikan di akhir maka harus dimulai dengan sesuatu yang baikjuga.Sebagai salah satu contoh yaitu kematian. Banyaknya orang-orang disekitar yang telah mendahuluinya untuk menghadap kepada Allah SWT membuatnya berfikir apakah orang-orang tersebut sebelum meninggal telah melakukan hal-hal baik, telah memiliki bekal yang cukup di akhirat kelak dan apakah mereka telah bertaubat sebelum ajal menjemput?. Pemikiran tersebutlah yang membuatnya sadar betapa sedikit amalan-amalan baik yang pernah dikerjakan dan ia belum mempersiapkan diri apabila sewaktu-waktu ajalnya tiba, karena sesungguhnya setiap manusia pasti akan mengalami kematian.

d. Pengaruh Orang Sekitar

Motif hijrah terakhir yang peneliti dapatkan dari hasil wawancara adalah pengaruh dari orang-orang sekitar yang telah lebih dulu melakukan hijrah.Dua dari empat informan mengatakan bahwa pengaruh orang-orang sekitar, baik keluarga maupun teman, berdampak besar atas kehidupan mereka. Apabila hidup dalam linkungan orang-orang baik, maka kita juga akan menjadi baik, begitupun sebaliknya. Salah satu informan mengatakan bahwa ia sangat tertarik melihat teman-teman kampusnya yang mengenakan gamis maupun rok panjang yang terlihat semakin anggun dan sopan. Hal tersebut menggerakkan hatinya untuk perlahan bergabung 
dengan komunitas muslimah kampus dan menyadari bahwa sesungguhnya keindahan seorang wanita muslimah apabila ia bisa menjada auratnya dengan baik.

\subsection{Trend dan Motif HijrahSebagai Faktor} Pendukung Perilaku Konsumen

Perilaku konsumen merupakan proses atau aktivitas yang dilakukan oleh seorang konsumenyang berhubungan dengan pencarian informasi dalam memenuhi keinginan seseorang sebelum membeli barang atau jasa.Terdapat beberapa faktor pendukung dalam menentukan perilaku konsumen sebelum menggunakan suatu barang, diantaranya adalah faktor pribadi dan faktor psikologi.Setelah menganalisa hasil dari wawancara dengan para informan,ditemukan bahwa trend dan motif hijrah seseorang merupakan bagian dari faktor pribadi dan psikologis, yakni kepribadian atau konsep diri dan motivasi.

Pertama,Trend hijrah yang terjadi saat ini membuat beberapa orang memutuskan untuk merubah cara berpakaian mereka dari yang dulunya suka memakai celana jeans dan baju terbuka, sekarang beralih ke penggunaan gamis dan jilbab syar'i dalam kegiatan sehari-hari yang juga berdampak pada meningkatnya pembelian busana muslimah oleh konsumen.Keputusan untuk melakukan perubahan tersebut termasuk dalamkepribadian atau konsep diri seorang pelaku hijrah dan merupakan bagian dari faktor pribadi yang mempengaruhi perilaku konsumen.Kedua, motif hijrah.Adanya motif dibalik keputusan seseorang untuk berhijrah merupakan sebuah motivasi dalam menentukan perilaku konsumenyang juga menjadi bagian dari faktor psikologis,yang mana motivasi merupakan keadaan pada diri seseorang yang mendorong orang tersebut untuk bertindak.Suatu kebutuhan menjadi satu dorongan bila kebutuhan itu muncul hingga mencapai taraf intensitas yang cukup atau mendesak.

4.4 Peran Trend dan Motif HijrahTerhadap Pembelian Busana Muslimah

Perkembangan industri halal di Indonesia memang telah menunjukkan perkembangan yang sangat pesat dalam beberapa tahun belakangan, baik dibidang kuliner, fesyen, wisata, kesehatan dan kosmetik. Hal ini didukung dengan adanyagerakan halal life style yang belakangan banyak canangkan oleh komunitas muslim dari berbagai daerah di Indonesia.Produk halal telah menjadi trend di kehidupan masyarakat global saat ini yang berdampak padapeningkatan permintaan konsumen pada produk-produk industri halal.Selain terkait keyakinan,produk industri halal dianggap baik dari segi 
kesehatan, keamanan, etika, dan ramah lingkungan(eco-friendly).

Negara-negara di dunia saat ini sedang berlomba-lomba ikut serta menjadi pelaku pasar halal. Misalnya Malaysia sebagai negara mayoritas muslim, selain gencar menerbitkan sertifikasi makanan dan minuman halal, negara jiran tersebut juga memperkenalkan pelabuhan bersertifikasi halal, seperti di Port Klang. Tidak hanya negara mayoritas muslim, negara minoritas muslim pun juga ikut menjadi pelaku pasar halal seperti; Jepang dengan taglinenya "Japan Muslim Friendly", Thailand dengan mengukuhkan diri sebagai dapur halal dunia, Australia dengan memproduksi dan mengekspor daging sapi halal, Korea Selatan dengankosmetik halal dunia, dan Cina dengan dominasi industri tekstil halal. Hal tersebut semuanya berkaitan dengan hasil pengembangan rantai pasok halal atau halal supply chain. ${ }^{9}$

Salah satu industri halal yang mengalami perkembangan secara signifikan di Indonesia saat ini adalah fesyen, bahkan pemerintah sedang mempersiapkan Indonesia sebagai kiblat fesyen muslim dunia di tahun 2020. Hal ini diwacanakan oleh Indonesia Islamic Fashion Consortium (IIFC)dansangat dimungkinkan mengingat

${ }^{9}$ Gema Industri Kecil Media Informasi dan Promosi industri Menengah, Indonesia Menuju Kiblat Fesyen Muslim Dunia, Edisi 61, Juni 2018. Hlm. 29 industri busana muslim di Indonesia telah mengalami pertumbuhan sejak 1990-an.

Salah seorang pelaku hijrah yang telah diwawancarai, Nur Indri, mengungkapkan bahwa yang menjadi salah satu kebutuhannya setelah berhijrah adalah busana muslim. ${ }^{10}$

“Awal berhijrah saya
memutuskan untuk berhenti
memakai jeans dan mulai
membiasakan diri untuk
berbusana muslim, tapi waktu
itu saya belum pakai gamis
seperti sekarang karena pada
awal saya berhijrah yaitu
sekitar tahun 2014/2015,
penjual gamismasih sedikit dan
itupun harganya juga mahal
jadi sebagai alternative saya
hanya menggunakan rok,
kemeja longgar dan jilbab yang
dilapis dua agar tidak
terawang."

Hal serupa juga disampaikan oleh pelaku hijrahlainnya bernama Ainun, ia mengatakan bahwa setelah berhijrah, salah satu perubahan yang dilakukan adalah merubah cara berpakaian, sehingga ia mulai memperbanyak koleksi busana muslimnya. ${ }^{11}$

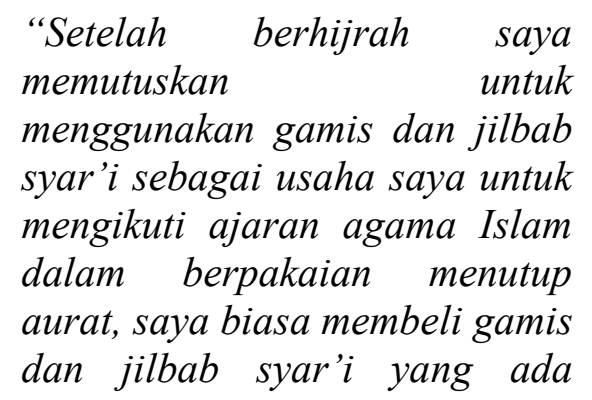
12 Juli 2019

${ }^{10}$ Wawancara dengan Nur Indri di Palu tanggal 12 Juli 2019 
ditokoonlineatau di offline
shop"

Berdasarkan keterangan dari

beberapa informan tersebut diatas, terlihat bahwa permintaan busana muslim bagi pelaku hijrah terus bertambah setiap tahunnya dikarenakan salah satu ciri dari seseorang yang memutuskan untuk berhijrah adalah merubah cara berpakaian mereka menjadi lebih syar'i dari sebelumnya. Pelaku hijrah yang dimaksud dalam penelitian ini adalah mereka yang memutuskan untuk berhijrah dan memutuskan untuk konsisten dalam menggunakan busana muslimah dalam kesehariannya.

Pendapat tersebut didukung dengan adanya hasil wawancara peneliti dengan beberapa pedagang busana muslimah di Kota Palu yang menunjukkan bahwa perkembangan busana muslimah yang sangat pesat terjadi sejak beberapa tahun terakhir dan mempengaruhi tingkat pembelian konsumen di pasar. Sebagaimana yang dikatakan olehseorang pemilik toko busan muslimah yang bernama Ilyas ${ }^{12}$

“...pada awannya membuka
toko ini saya belumberjualan
busana muslim melaikan
menjual cincin batu akik,
namun di tahun 2014 saya
melihat banyak orang yang
memakai busana muslim/gamis
di bandara, mereka orang-
orang Palu yang baru datang
dari luar kotakebanyakan

${ }^{12}$ Wawancara dengan Ilyas di Palu tanggal 15 Juli 2019 memakai gamis. Dari situ saya berpikir sepertinya warga kota Palu suka memakaigamis dalam aktifitas sehari-hari, bukan hanya saat mengikuti pengajian atau pesta saja”

Kemudian usaha pak Ilyas beralih dari menjual cincin menjadi busana muslim karena beliau beranggapan bahwa peluang usaha busana muslim di Kota Palu akan berkembang dengan baik kedepannya. Namun ternyata salah satu kendala dari penjualan busana muslim kala itu adalah harga. Harga busana muslim saat itu tergolong mahal, salah satu penyebabnya karena belum banyak permintaan masyarakat akan busana muslim. Seiring berjalannya waktu, perlahan minat masyarakat terhadap busana muslim mulai meningkat didukung dengan mulai berkembangnya trend hijrah. Untuk mengimbangi minat beli dengan harga jual, pak Ilyas bekerja sama dengan penjahit konveksi untuk pembuatan busana muslim dan menjualnya dengan harga yang terjangkau oleh semua kalangan.

“...kami melihat banyak
masyarakat yang ingin membeli
gamis namun terkendala harga
yang mahal, makanya kami
menjual gamis konveksi agar
harganya bisa lebih murah
namun kami juga tetap
memperhatikan
barang."

Menurut pak Ilyas, alasan beliau menjual gamis konveksi adalah agar dapat 
memudahkan masyarakat yang ingin berhijrah dan merubah penampilan mereka menjadi lebih syar'i, mengingat saat itu harga gamis di pasaran masih belum sepenuhnya terjangkau untuk semua kalangan sedangkan permintaan akan busana muslim sudah mulai meningkat. Karena sesungguhnya dalam aktifitas jual beli yang dilakuan, ada niat untuk saling memudahkan bagi para wanita muslimah yang berusaha untuk merubah penampilannya menjadi lebih tertutup dari sebelumnya.

Dampak dari trend hijrah juga dirasakan langsung oleh salah seorang pedagang jilbab di kota Palu bernama Ibu Hana. Ia mengatakan bahwa minat masyarakat terhadap pembelian jilbab meningkat tiap tahunnya.

“..tahun 2012 yang lalu kami jualan barang campuran dan jilbab, tapi kami melihat minat orang-orang terhadap jilbab itu lebih besar jadi kami memfokuskan penjualan ke jilbab saja karena peluang bisnisnya lebih menjamin. Sekarang, toko ini adalah toko jilbab ke dua kami.",13

Meningkatnya permintaan hijab tidak terlepas dari Trend hijrah yang terjadi di masyarakat saat ini.Jika dahulu model jilbab syar'i hanya di minati oleh para ibu-ibu, namun sekarang model jilbab syar'i juga dicari oleh para remaja muslimah.Hal ini

${ }^{13}$ Wawancara dengan Hana di Palu tanggal 15 Juli 2019. disebabkan karena model jilbab sudah banyak yang lebih modis dan modern dari sebelumnya, tidak hanya monoton dengan satu model saja.Ibu Hana menyampaikan bahwa sebagai penjual harus pintar-pintar melihat trend model jilbab yang sedang berkembang saat ini agar minal beli masyarakat semakin meningkat.

Salah satu yang menjadi kebutuhan wanita muslimah setelah berhjrah adalah busana muslim, baik gamis maupun jilbab syar'i, keduanya merupakan item yang sangat dibutuhkan oleh seseorang yang baru mulai berhijrah. Tak heran jika belakangan ini pembelian gamis dan jilbab syar'i semakin meningkat dikarenakan banyak wanita muslimah yang ingin berubah menjadi lebi baik dari sebelumnya, begitupun dengan penampilan mereka.

\section{KESIMPULAN}

Berdasarkan hasil penelitian yang telah dilakukan, maka dapat ditarik kesimpulan bahwapermintaan busana muslimah yang terus meningkat setiap tahunnya tidak terlepas dari peran serta adanya trend hijrah yang marak dilakukan beberapa tahun terakhir.Trend hijrah maupun motif yang melatar belakangi seseorang untuk berhijrah, keduanya mengambil peran dalam menentukan perilaku konsumen muslim untuk melakukan pembelian busana muslimah karena merupakan bagian dari 
faktor yang mempengaruhi keputusan konsumen yaitu faktor pribadi dan faktor psikologis.

\section{Daftar Pustaka}

Gema Industri Kecil Media Informasi dan Promosi industri Menengah, Indonesia Menuju Kiblat Fesyen Muslim Dunia, Edisi 61, Juni 2018.

Hair, Abdul, "Fenomena Hijrah di Kalangan Anak Muda", Detik News, 7 Juli 2019.https://news.detik.com/kolom/d3840983/fenomena-hijrah-di-kalangananak-muda.

Ismail, Muhammad Taufiq dan Zaenal Abidi, "Kontekstualisasi Hijrah Sebagai Titik Tolak Pembaharuan Pendidikan" Jurnal SUHUF, Vol. 29, No. 1, Mei 2017.

Karim, Adiwarman, Ekonomi Mikro Islami, The International Institute of Islamic ThougtIndonesia, Jakarta, 2003.

Sejarah Pemikiran Ekonomi Islam, Edisi ketiga, Jakarta: PT. RajaGrafindo Persada, 2010.

Kurniati, "Teori Perilaku Konsuman Perspektif Ekonomi Islam", Jurnal Ekonomi Syariah Indonesia, Vol. VI, No. 1, Juni 2016.

Mangkunegara, Anwar Prabu, Perilaku Konsumen, Bandung: Refika Aditama, 2002, dalam Kurniati, "Teori Perilaku Konsuman Perspektif Ekonomi Islam”,
Jurnal Ekonomi Syariah Indonesia, Vol. VI, No. 1, Juni 2016.

Moleong, Lexy J, Metodologi Penelitian Kualitatif, (Cet XIII), Bandung: Remaja Rosda Karya, 2001.

Muhammad. Ekonomi Mikro dalam Perspektif Islam. Yogyakarta: BPFE, 2004.

Muntaha, Ahmad, "Fenomena Hijrah Kaum Muda". NU Online, 28 Juni 2019, https://islam.nu.or.id/post/read/95591/f enomena-hijrah-kaum-muda.

Nasution, Mustafa Edwin dkk.Pengenalan Eksklusif Ekonomi Islam. Jakarta: Kencana, 2007.

Sakti, Ali "Sistem Ekonomi Islam." Filosofi Dan Bangunannya (2003), dalam Kurniati, "Teori Perilaku Konsuman Perspektif Ekonomi Islam", Jurnal Ekonomi Syariah Indonesia, Vol. VI, No. 1, Juni 2016.

Setiawan, Erik, dkk. "Makna Hijrah Pada Mahasiswa Fikom Unisba di Komunitas ('followers') Akun 'LINE@DakwahIslam”MediaTor, Vol. 10 (1), 28 Juni 2017.

Sumar'in, Ekonimi Islam, Sebuah Pendekatan Ekonomi Mikro Perspektif Islam, Jakarta: Graha Ilmu, 2010.

Syukur, Yanuardi, "Tren Hijrah dan Halal Muslim Milenial" ,Academia.edu. Paper online, 7 Juli 2019 https://www.academia.edu/37101944/ Tren_Hijrah_dan_Halal_Muslim_Mile nial 